altogether, and the balance of $£ 70,000$ a year will be provided br associations of manufacturers who make plant an 1 equipment for using coal.

Among the 'urposes of the scheme is the development of new $\mathrm{f}$ rocesses based on coal which will create employment and strengthen export trade. Improvements in methods of using coal for light and power, for the production of materials for the chemical industry, the development of such substances as plastics, and the production of liquid fuels will be among the subjects of investigation. Sir Evan Williams said that the Ministry of Planning has asked the Coal Utilization Research Association to carry forward to the production stage economical domestic heating appliances which have been devised so that they may be procurable for the post-war house building programme.

\section{Geographical and Geological Research in the U.S.S.R.}

ONE of the first aims of the Russian Academy of Science founded by Peter I in 1724 was the geographical study of the country's natural resources and populations. Geography and geology have also been kept in the forefront of the manifold activities of the present Academy of Sciences. In 1920 a systematic scientific study of raw materials was undertaken with the view of co-ordinating the industrialization of the Soviet Union with the distribution of essential minerals. The work has borne fruit, for example, in the development of great apatite, copper and nickel industries in the arctic tundras, and of the sulphur industry in the sands of Karakum, and in the exploration of the vast oilfields known as the 'second Baku', lying between the River Kama and the Ural Mountains. These last explorations proved of inestimable value when the wholesale transfer of industry to the east was made necessary by the German invasion.

During the past twenty-five years the Acaderny has sent more than five hundred expeditions to every part of the Soviet Union to study geological and agricultural resources. In 1917 only 10 per cent of the country had been surveyed geologically; now the proportion is 50 per cent. Maps of soils and vegetation have also been prepared, as well as general maps for European Russia. Geological calculations show that the Union occupies first place among all countries of the world in respect of resources of iron, manganese, apatite, phosphorites, potash salts and niobium, and second place in respect of coal, zinc, lead and nickel.

\section{The Ukrainian Academy of Sciences}

AN account of the war-time activities of the Ukrainian Academy of Sciences has recently been received from the U.S.S.R. Early in the War the Academy was transferred to the interior of the country, where it resumed work. It was faced with complex problems which had to be tackled at short notice, in particular the readjustment of its entire scientific activities to meet the requirements of national defence and an expanding production programme. At the present time a large part of the Academy's work relates to aircraft and tank construction. Comprehensive studies are being made of the power resources of the Urals and Bashliria, where new war industries have sprung up.

Biological institutes are investigating new methods of treating wounds and preventing infection. An antireticular cytotoxic serum has already been placed at the disposal of hospitals and has proved its value in accelerating healing processes. Close contact has been established between the Academy research workers and the war factories. A special technical committee has been set up to co-ordinate the Academy's research programme with the demands of the war effort. Another committee is studying the scientific problems of reconstruction that will require immediate solution when the Ukraine is liberated from the German yoke.

\section{The Sky in North Africa}

A sEcond edition of the "Star Atlas for the Latitude of Egypt", compiled by H. E. Hurst, M. R. Madwar and A. H. Samaha, and published by R. Schindler, Cairo, will be welcomed by members of the British forces campaigning in North Africa. It is designed for use in latitude $30^{\circ} \mathrm{N}$, but can be employed without difficulty between $20^{\circ}$ and $40^{\circ} \mathrm{N}$.; it may therefore be of service in North India, South China, and the southern United States as well. It consists of six circular star charts covering the whole sky visible throughout the year in thoselatitudes, the centre of each chart being the zenith of the observer and the circumference his horizon. The successive charts represent the appearance of the sky throughout the twenty-four hours of a given day at four-hour intervals, or alternatively throughout the year at a given time of night at two-month intervals. A transparent graticule of the same size of the charts can be used to estimate altitudes and azimuths of the stars.

The text accompanying the charts illustrates their use and gives a clear description of the apparent movements of the stars, the planets, and the sun and moon, and even touches upon the modern conception of the structure of the galaxy. In solving many practical problems the atlas may prove invaluable; for example, in choosing a suitable guide star for marching on a given bearing, in reckoning the azimuth of a terrestrial object, and in estimating the time during the night. Such information must often have been in demand in the quick-moving campaigns of the past two years. When the charts are not employed in such immediately useful ways, the accompanying notes may awaken the scientific interest of those living in lonely camps with little to occupy their spare time. The atlas is handy in size and the charts are excellently drawn and reproduced.

\section{Production of Synthetic Rubber in Sweden}

THE scarcity of rubber is being felt more and more in Sweden. While through a rapid perfection and large-scale adoption of producer-gas the motor fuel problem has been relatively satisfactorily solved, it is now the shortage of rubber and lubricants that is the great cause for anxiety and which has made necessary the imposition of further restrictions on motor traffic. To try to improve the situation, experiments with the production of synthetic rubber have been going on for some time at various institutions. Promising results have been reported from the Physico-Chemical Institute at Uppsala, where experimental production has been carried on under the guidance of Prof. The Svedberg, as well as by the Swedish cellulose concern, Mo and Domsjö, which has evolved a product that is stated to be able to replace rubber for many purposes and which will be produced on a commercial scale in the near future. A young Swedish scientific worker, Dr. Gosta Ehrensvärd, of the Wenner-Gren Institute in Stockholm, has 
succeeded in developing a kind of artificial rubber which seems to possess several good qualities. Production on a small scale has been going on for some time at one of the rubber factories of the Swedish Co-operative Wholesale Society, which is supporting his researches and will probably exploit the new product. It belongs to the so-called 'thioplast' products, the weak point of which has hitherto been that they could not be vulcanized at a high temperature. This can, however, be done with the Ehrensvärd rubber. The unpleasant odour that formerly characterized such products has also been eliminated. Nothing has so far been said about the composition of the new product or of what raw materials it is being made, except that it is based on domestic raw materials and that the Swedish forests, in this as in so many other cases, will play an important part.

\section{Photographic Analysis of Motion}

A LECrURE on the "Photographic Analysis of Motion" was delivered at the Royal Institution on December 11 by Mr. E. R. Davies, director of research, Messrs. Kodak, Ltd. He said that the value of photography in the analysis of movements too rapid for the eye to follow was demonstrated, and the method successfully applied, in the classical investigations of Muybridge and Marey before the introduction of the dry plate in 1871. The great convenience of the new process compared with the laborious wet-plate technique, and its enhanced sensitivity, brought about many triumphs towards the end of the nineteenth century. The movements of animals and the flight of birds were analysed; projectiles travelling at speeds in excess of that of sound photographed; and the propagation of flames in gaseous combustion was followed. Modern progress had depended to a large extent upon the introduction of the cold cathode discharge tube in place of the far less luminous electric spark ; on advances in the design of cinematographic and other types of camera; on the introduction of photographic materials of greatly increased sensitivity; and on the application of the photo-electric cell and the microphone to the problem of synchronizing the action with the camera exposure. Instantaneous photographs can now be taken with exposures of less than a millionth of a second and cinematograph pictures with a frequency in excess of 4,000 a second. A valuable tool has become available to science and industry, and has proved its worth in many fields. Its use in the design and testing of high-speed machinery is of particular importance at the present time.

\section{Cancer-producing Mineral Oils}

ADDREssing a recent meeting of the Manchester University Branch of the Association of Scientific Workers, Mr. R. Lyth deseribed how methods of preventing certain types of occupational cancer have been discovered. External cancers which are prevalent among Scottish shale oil workers have also increased among cotton spinners, since the introduction of mineral lubricating oils. In the Cancer Research Department of the University of Manchester, cancers have been produced in mice by repeatedly painting their skins with mineral oils. Shale oil was found to be much the most active carcinogenically, while Russian oil was one of the least active oils. The refractivity $(\mu-1) / D$, where $\mu$ is the refractive index and $D$ the density, could be roughly correlated with the carcinogenic properties, and used as an index of them. In the laboratory, various methods of reducing the activity of oils were found, but the cotton industry has found it more practicable to avoid the use of the more dangerous oils such as shale oil. For the shale oil workers themselves, the regular use of certain ointments has proved beneficial. Efforts to isolate the carcinogenic constituents of mineral oils have not yet fully succeeded. The meeting learnt with regret that the Cancer Research Department of the Univer. sity of Manchester is being closed.

\section{Frequency Stability of Radio Circuits}

AT a meeting of the Students Section of the Institution of Electrical Engineers held on November 16, Mr. C. W. Eggleton read a paper on "The Frequency Stability of Tuned Circuits". The author dealt with the conditions with which it is necessary to comply in the design of commercial radio receivers in order to secure a satisfactory degree of frequency stability in the various tuned circuits of the receiver. The majority of broadcasting receivers in use at the present time are of the supersonic heterodyne type using a local oscillator, and it is the frequency stability of this oscillator which usually determines the stability of the whole receiver, particularly when the required reception is within the short-wave band. Variations of the frequency of any tuned circuit are occasioned chiefly by the effect of temperature, and to a lesser extent by condensed moisture, on the electrical characteristics of inductance coils and condensers. In the paper, the author directed attention to the desirable properties of the materials used in the construction of these components, and to the importance of various features of design. An important point in connexion with the layout of the whole receiver is to ensure that the local oscillator and the main radio frequency circuits are kept as far away as possible from the power frequency components, which largely form the main source of heat generated in the receiver.

\section{London Gulls}

IT is reputed (Countryside, 12 , No. 5,$93 ; 1942$ ) that it is exactly fifty years since flocks of gulls began to winter on the London Thames, in the severe winter of 1892. Most of these birds are black-headed gulls, but whether or not the severe winter of 1892 was the origin of gulls frequenting the Thames embankment in numbers is not accepted by all ornithologists. T. L. Bartlett notes that sixty years ago the occasional appearance of gulls in London caused unusual interest amongst ornithologists, and although there were occasional records of gulls passing up-river in severe weather, the first winter occupation of central London by black-headed gulls appears to be the severe winter of 1892 at Blackfriars Bridge, where new legislation protected them from gunshot. But the black-headed gull has not really changed its habit : it was always known as an inland as well as coastal bird. The difference in the past fifty years has been its great increase in numbers - which may be from biological reasons-and its protection under the bird laws which give it encouragement to stay on waters where formerly it was persecuted and driven away. Bartlett, however, suggests also that they were encouraged to winter on the Thames after 1892 by the public feeding the gulls with large sprats, and fifty years of embankment feeding with bread have changed its ways to a town gull. The habits of Thames gulls have, however, been given exaggerated importance. Similar 